slight increase in the risk of an important adverse outcome might result in substantial absolute numbers of individuals being affected.

IAIN ChALMERS

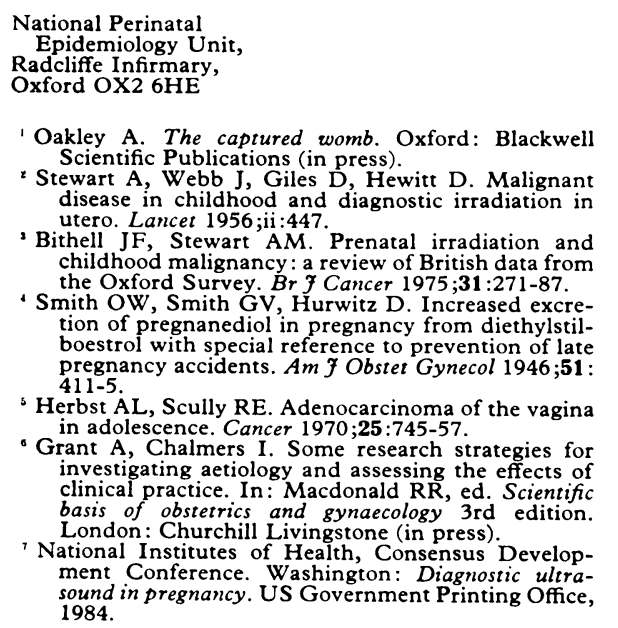

\section{The importance of $\mathrm{pH}$ and blood gas monitoring after overdoses of tricyclic antidepressants}

SIR, - We strongly support the conclusion of Dr D Hodes (16 June, p 1800) that arterial pH and blood gas monitoring are mandatory in patients severely poisoned with tricyclic antidepressants. It is our experience in adults that such patients are at risk of developing metabolic acidosis, which may lead to cardiac arrhythmias. Accordingly, we measure $\mathrm{pH}$ and blood gases at hourly intervals, using an indwelling arterial cannula, in all patients poisoned with tricyclic antidepressants in grade III or IV coma (Edinburgh scale). The value of this approach is shown by the following two cases.

An 18 year old man was admitted in g:ade III coma after an overdose of amitriptyline and ethanol. His blood pressure was $120 / 80 \mathrm{mmHg}$ with a pulse rate of $80 / \mathrm{min}$. He was intubated, gastric lavage was performed, and activated charcoal was instilled in the stomach. Three hours after admission (11 hours after ingestion) when the plasma drug concentrations were amitriptyline $0.25 \mathrm{mg} / \mathrm{l}$, nortriptyline $0.03 \mathrm{mg} / \mathrm{l}$, and ethanol $1250 \mathrm{mg} / \mathrm{l}$, the arterial $\mathrm{pH}$ fell to $7 \cdot 28$ with carbon dioxide pressure $5.01 \mathrm{kPa}(38 \mathrm{mmHg})$ and oxygen pressure $15 \mathrm{kPa}$ (112 mmHg) (fractional inspired oxygen $24 \%$ )-a metabolic acidosis with carbon dioxide retention. He was treated with $100 \mathrm{mmol}$ sodium bicarbonate intravenously after which his arterial $\mathrm{pH}$ became normal at $7 \cdot 42$. Cardiac arrhythmias were not observed, and he made a full physical recovery.

A 35 year old woman was admitted having taken a substantial overdose of amitriptyline and a minor overdose of Distalgesic (dextropropoxyphene and paracetamol) and ethanol two hours previously. She was drowsy (grade I coma), normotensive $(120 / 70 \mathrm{mmHg})$, and had a pulse rate of $80 / \mathrm{min}$. Gastric lavage was performed. Over the ensuing 10 hours her level of consciousness deteriorated to grade IV coma and she had two generalised seizures lasting 30 and 5 seconds respectively; mechanical ventilation was not required and blood $\mathrm{pH}$ and gases were normal. Seventeen hours after admission she developed a metabolic acidosis with carbon dioxide retention ( $\mathrm{pH} 7 \cdot 28$, carbon dioxide pressure $5.79 \mathrm{kPa}$ (43 $\mathrm{mmHg}$ ), oxygen pressure $22.9 \mathrm{kPa}(172 \mathrm{mmHg}$ ) (fractional inspired oxygen $35 \%$ ), and plasma drug concentrations were as follows: amitriptyline $0.82 \mathrm{mg} / 1$, nortriptyline $0.43 \mathrm{mg} / \mathrm{l}$, dextropropoxyphene $<0.05 \mathrm{mg} / \mathrm{l}$, and norpropoxyphene $0.52 \mathrm{mg} / \mathrm{l}$. Paracetamol and ethanol were not detected. The acidosis was corrected with $100 \mathrm{mmol}$ of sodium bicarbonate, and she recovered.

Tricyclic antidepressant poisoning may be associated with the development of a metabolic acidosis: our first patient, who was only moderately poisoned, developed an acidosis 11 hours after ingestion, whereas the second patient, who was more severely poisoned, did not develop an acidosis until 19 hours afterwards. As shown by the case of Dr Hodes and by our own experience, normal respiratory compensation for the metabolic disturbance is suppressed, possibly by a direct respiratory depressant action of the drug. The consequent accumulation of carbonic acid, uncompensated by hyperventilation, facilitates the development of acidaemia. In the absence of hyperventilation, this acidosis will not be detected unless arterial blood gases are measured regularly.

We concur with Dr Hodes that acidosis is important in the genesis of tricyclic antidepressant induced arrhythmias and that its early detection and correction is crucial if a potentially fatal outcome is to be prevented. We believe that in severe poisoning with tricyclic antidepressants the regular assessment of arterial acid base status is more important than continuous electrocardiographic monitoring.

We are grateful to Keith Hale for his assistance in measuring the drug concentrations.

B M BUCKLEY D A R BOLDY J A VALE

West Midlands Poisons Unit, Dudley Road Hospital,
Birmingham B18 7QH

\section{Ethical issues in prenatal diagnosis}

SIR,-Dr A V Campbell's leading article (2 June, p 1633) distinguishes correctly between what is legal and what is ethical. What may be legal in one society may be anathema in another, and in British society what is legal is not necessarily ethical to many in the same society. What we should be debating are the principles governing laws and behaviour, and I am convinced that there are ethical principles in prenatal diagnosis which transcend the details of which technique is least harmful. These principles can be illustrated by just two personal experiences.

I was born in the Krobo tribe with extra digitsa Mendelian dominant condition with a $1 \%$ incidence at birth in Ghana. ${ }^{1} \mathrm{Had}$ I been born a few miles south east across the Volta River there would have been great rejoicing because local tribal tradition had it that I was destined to be rich. If my mother had given birth to me a few miles north west beyond the hills I would not be here to write to you-I would have been drowned soon after birth. Fortunately the Krobos were neutral to extra digits, but until the government forbade the practice some tribal elders took it on themselves to decide which genes ought to be allowed to survive.

A GP referred a 45 year old woman with deteriorating memory to my outpatients when $I$ was a locum consultant physician in London. The patient had no other complaints and was not aware of her subtle physical signs of Huntington's chorea. She was a successful civil servant who had had what I considered a most fruitful 45 years. Imagine my chagrin, therefore, when I read that Huntington's chorea could be identified prenatally and got rid of. Some scientific tribesmen have taken it upon themselves to advise that all the remarkable genes that go to make potentially successful civil servants should be sacrificed and a life of 45 years nipped in the bud just because the Huntington chorea gene had become visible; society, they think, should not be burdened with looking after such patients. Scientists now determine. the quality of life that society should allow, and they programme society carefully and insidiously to accept their guidance on these matters.

History shows that often a few pressure groups, or even a single person, can decide what is good for the whole society. Nazi tribal society decided to get rid of Hebrew genes and programmed people to accept the plan as good for society. Now we must be careful not to allow scientific pressure groups whose only qualification is that they can see a particular gene to make us think that they are also qualified to tell us who should be allowed to survive and who should be aborted. My views about prenatal diagnosis and sickle cell disease are not new. ${ }^{2.4} \mathrm{My}$ fellow Krobo tribesmen did not spend time debating details like the most humane way to drown me at birth to cause least hurt to my mother, nor did they ever ponder how my three siblings with sickle cell disease could have been identified in utero and got rid of. No, they got hold of the vital principle that I was literally more than extra digits and my two brothers and sister with sickle cell disease had other genes that endeared them to my parents.

The late Dr Schaeffer urged that those of us who did not like where scientific humanism was leading us should speak out before it was too late. ${ }^{5}$ Writing from a department of christian ethics and practical theology, Dr Campbell would have been amply excused by the most ardent adherents to prenatal diagnosis if he had emphasised that the ethics of scientific humanism and Christian ethics are sometimes, if not often, poles apart.

\section{Felix Konotey-Ahulu}

Harley Street Centre,
London W1N IAA

' Konotey-Ahulu FID. Male procreative superiority index (MPSI): the missing coefficient in Africa anthropogenetics. Br Med f 1980;281:1700-2.

' Konotey-Ahulu FID. Antenatal diagnosis of haemoglobinopathies. Lancet 1977;i:597-8.

Konotey-Ahulu FID. Ethics of amniocentesis and selective abortion for sickle cell disease. Lancet $1982 ;$ i:38-9.

Konotey-Ahulu FID. Sickle cell disease: the case for family planning. Accra; Astab Books, 1973.

London: Marshall, Morgan and Scott, 1980.

\section{Asthma in children}

SIR,-Dr John Price's article (23 June, p 1895) reflects much of the current orthodox teaching on childhood asthma. We believe, however, that in the management of acute attacks current orthodoxy leaves much to be desired.

The clear implications of Dr Price's flow chart is that systemic steroids are a last resort for children in hospital. General practitioners (and parents) are apparently given no other options but to give bronchodilators and decide whether to take the child to hospital. This philosophy is surely irrational in view of the safety and efficacy of short course steroid treatment and the repeated findings of underuse of steroids in most surveys of asthma deaths. In addition, this philosophy encourages a dependence on hospitals and fails to meet the needs of families who live in rural areas or who go abroad for their holidays.

We advocate a radically different approach whereby short courses of oral prednisolone are used early in acute attacks by parents, who should be educated on the indications for starting a course. Such a policy should include instructions on indications for hospital referral, 